\title{
PENGEMBANGAN LEMBAR KERJA SISWA BERBASIS INKUIRI TERBIMBING PADA MATERI HIDROLISIS GARAM DI MAN 1 BANJARMASIN
}

\section{The Development of Guided Inquiry-Based Student Worksheets on the Topic of Salt Hydrolysis in MAN 1 Banjarmasin}

\author{
Zainab*, Novi Rahmawanti, Herlina Apriani \\ Program Studi Pendidikan Kimia Fakultas Keguruan dan Ilmu Pendidikan Universitas \\ Islam Kalimantan (Uniska) Muhammad Arsyad Al Banjari, Banjarmasin \\ email: nunazainab1@gmail.com
}

\begin{abstract}
Abstrak. Bahan ajar LKS yang biasa digunakan di sekolah relatif kurang menarik karena terkesan monoton, tidak berwarna, tampilan tidak menarik, tidak sesuai dengan kebutuhan siswa, dan digunakan hanya untuk latihan soal saja, sehingga siswa tidak mampu membangun konsep itu sendiri. LKS didesain dengan warna yang cerah, memuat gambar dan karakter disertai pendekatan induktif dan langkah-langkah inkuiri terbimbing. Tujuan penelitian ini adalah menguji apakah LKS berbasis inkuiri terbimbing valid dan praktis digunakan sebagai bahan ajar pada materi hidrolisis garam di MAN 1 Banjarmasin. Metode penelitian yang digunakan adalah metode penelitian dan pengembangan (Research and Development atau R\&D) melalui tahap 1-8. Sampel dalam penelitian ini adalah siswa kelas XI MIA 1 dengan jumlah 29 siswa. Hasil penelitian menunjukkan valid dengan nilai rata-rata 95,33 dengan kriteria sangat layak dan praktis dengan nilai rata-rata 22,24 dengan kriteria sangat baik. Berdasarkan hasil penelitian maka dapat diambil kesimpulan bahwa LKS berbasis inkuiri terbimbing valid, praktis dan dapat dijadikan sebagai bahan ajar pada materi hidrolisis garam. LKS ini dapat digunakan sebagai media pembelajaran yang menarik dan mampu melatih kemampuan berpikir kritis siswa melalui inkuiri terbimbing pada materi hidrolisis garam.
\end{abstract}

Kata kunci: penelitian pengembangan, lembar kerja siswa, inkuiri terbimbing, hidrolisis garam

Abstract. Worksheets as teaching materials usually used in schools are relatively
unattractive because they seem monotonous, colorless, unattractive, not relevant to
students' needs, and are used only for question practice. Hence, students are
unable to construct the concept themselves. Worksheets were designed in bright
colors, containing pictures and characters accompanied by an inductive approach
and guided inquiry steps. The purpose of this study was to test whether the guided
inquiry-based worksheets were valid and practical as teaching material for salt
hydrolysis in MAN 1 Banjarmasin. The research method used was the research
and development method (R\&D), according to Sugiyono (2016), through stages 1 -
8. The sample in this study was 29 students of class XI MIA 1. The results showed
that the worksheet is valid with an average of 95.33 categorized as very feasible,
and the practical criteria were 22.24 , with very good criteria. Based on the
research results, it can be concluded that guided inquiry-based worksheets are
valid, practical, and can be used as teaching material on salt hydrolysis topic. The 
worksheets can be used as interesting learning media and practice the students' critical thinking skills through guided inquiry on salt hydrolysis topic.

Keywords: research development, student worksheets, guided inquiry, salt hydrolysis

\section{PENDAHULUAN}

Berdasarkan hasil observasi yang dilakukan dengan guru kimia di sekolah MAN 1 Banjarmasin didapat informasi bahwa bahan ajar yang digunakan adalah buku LKS. Buku LKS di sekolah digunakan hanya untuk latihan soal saja, kurang menarik karena di dalam buku LKS masih terkesan monoton (tidak berwarna dan tampilan tidak menarik), tidak sesuai dengan kebutuhan siswa karena materi terlalu singkat, contoh soal sedikit dan tidak bervariasi. Lembar kerja siswa yang kita temui biasanya berupa materi yang sudah jadi, sehingga siswa tidak membangun konsep itu sendiri. Dengan menggunakan bahan ajar LKS diperlukan model pembelajaran yang dapat memudahkan siswa dalam memahami materi.

Salah satu model pembelajaran yang cocok dengan pembelajaran kimia adalah model inkuiri terbimbing. Menurut Wiyanto dkk (2017) dalam Ika dkk (2017) hal ini karena model pembelajaran inkuiri terbimbing berfokus pada mencari dan menemukan sendiri makna dari pembelajaran secara sistematis, kritis dan logis dengan aktifitas ilmiah siswa secara menyeluruh sehingga dapat membantu meningkatkan rasa percaya diri dan hasil belajar siswa. Hal ini didukung dengan penelitian dari Mattew dan Kenneth (2013), Ningsyih dkk (2016), Ika dkk (2017), Sari dkk (2017), Pujiastuti dkk (2018), Pratiwi dkk (2019) yang membuktikan bahwa penggunaan model pembelajaran inkuiri terbimbing dapat meningkatkan hasil belajar siswa.

Pembelajaran menggunakan bahan ajar LKS berbasis inkuiri terbimbing dapat membantu siswa untuk lebih mudah dalam memahami materi. Hal ini didukung oleh hasil penelitian Rizalini dan Sofyan (2018), Latifah dkk (2016), Resita dkk (2016) yang melaporkan bahwa dengan penggunaan LKS berbasis inkuiri terbimbing praktis diterapkan dalam pembelajaran, menarik dan efektif digunakan sebagai bahan ajar. Untuk membuat LKS berbasis inkuiri terbimbing juga perlu memperhatikan materi yang cocok.

Menurut Agustina dkk (2015) materi hidrolisis garam memiliki karakteristik konseptual, algoritmik dan abstrak. Materi hidrolisis garam tidak terlalu banyak hitungan sehingga cocok dengan inkuiri terbimbing. Berdasarkan data pada tahun ajaran sebelumnya, tepatnya pada tahun 2018/2019 semester genap menunjukkan bahwa materi hidrolisis garam merupakan materi dengan rata-rata nilai dan proporsi ketuntasannya paling rendah. Maka dari itu perlu dilakukan penelitian yang berjudul "Pengembangan Lembar Kerja Siswa Berbasis Inkuiri Terbimbing Pada Materi Hidrolisis Garam Di MAN 1 Banjarmasin".

\section{METODE PENELITIAN}

Jenis dan desain penelitian yang digunakan dalam penelitian ini adalah penelitian dan pengembangan (Research and Development atau R\&D) melalui langkah 1-8 menurut Sugiono (2016). Penelitian dilakukan di MAN 1 Banjarmasin. Populasi dalam penelitian ini adalah siswa kelas XI MIA dengan jumlah 82 siswa. Sampel dalam 
penelitian ini adalah seluruh siswa kelas XI MIA 1 dengan jumlah 29 siswa. Teknik pengumpulan data yang digunakan adalah teknik nontes berupa angket.

Instrumen yang digunakan dalam penelitian ini ada 3, yaitu angket kevalidan, kepraktisan dan respon siswa terhadap bahan ajar LKS inkuiri terbimbing. Angket kevalidan terdiri atas aspek isi, bahasa, kegrafisan, dan sajian. Angket kepraktisan berupa respon siswa terhadap pembelajaran menggunakan bahan ajar LKS berbasis inkuiri terbimbing. Skala pengukuran yang digunakan pada angket menggunakan skala likert.

\section{HASIL PENELITIAN DAN PEMBAHASAN}

\section{Langkah 1 Potensi dan Masalah}

Penelitian ini berawal dari wawancara langsung dengan guru kimia di MAN 1

Banjarmasin. Berdasarkan hasil wawancara, didapat informasi bahwa pembelajaran biasanya menggunakan buku LKS, tapi hanya digunakan saat latihan soal saja. Buku LKS yang biasa digunakan kurang menarik karena di dalam buku LKS masih terkesan monoton, tidak berwarna, tampilan tidak menarik, tidak sesuai dengan kebutuhan siswa. Untuk itu diperlukan sebuah pengembangan LKS yang dapat digunakan pada saat pembelajaran berlangsung.

Guru mengharapkan adanya bahan ajar yang mudah dipahami, dimengerti dan sesuai dengan kebutuhan oleh siswa. Dalam segi tampilan yang memuat gambar-gambar yang menarik siswa, seperti warna yang lebih cerah karena lembar kerja yang tersedia memiliki warna yang kusam, bahasa yang digunakan mudah dipahami dan memuat materi yang mudah dipahami oleh siswa agar dalam proses pembelajaran siswa menjadi lebih aktif.

\section{Langkah 2 Pengumpulan Data}

Pada tahap ini peneliti mengumpulkan informasi yang menunjang pengembangan produk berupa LKS berbasis inkuiri terbimbing. Peneliti mengambil referensi dari beberapa sumber yang relevan seperti jurnal. Sebelumnya, peneliti melihat buku LKS yang dipakai siswa di sekolah. Contoh buku LKS di sekolah dapat dilihat pada gambar 1 .

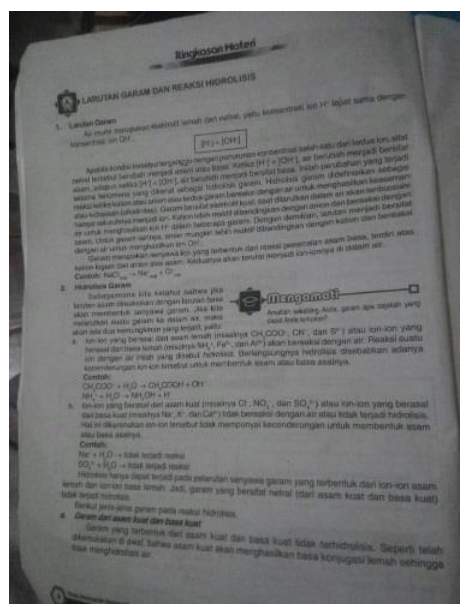

Gambar 1. Buku LKS di Sekolah 


\section{Langkah 3 Desain Produk}

LKS dibuat dengan ukuran kertas A4 yaitu $21 \mathrm{~cm}$ x 29,7 cm. Di dalamnya memuat materi hidrolisis garam yang dikemas dengan pendekatan induktif dan langkahlangkah inkuiri terbimbing. Menurut Ningsyih (2016) inkuiri terbimbing dalam pembelajaran bertujuan untuk membantu siswa mengembangkan keterampilan berpikir intelektual dan keterampilan lainnya seperti keterampilan menemukan jawaban yang berawal dari keingintahuan siswa dan mengajukan pertanyaan.

Ada dua karakter dalam LKS yang bertujuan untuk membantu siswa dalam memahami materi, yaitu Humaira dan Professor. Humaira merupakan siswa MA yang mempunyai rasa ingin tahu tinggi. Disamping itu, ada Professor yang akan membantu Humaira untuk memenuhi rasa ingin tahunya.

LKS ini didesain untuk tiga kali pertemuan. Dimana pertemuan pertama memuat materi tentang: (1) definisi hidrolisis garam, (2) jenis hidrolisis yang terjadi pada larutan garam, (3) sifat larutan garam terhidrolisis berdasarkan asam basa penyusunnya. Pertemuan kedua memuat materi tentang: (1) tetapan hidrolisis (Kh), (2) $\mathrm{pH}$ larutan garam bersifat asam yang terhidrolisis parsial dan total. Terakhir, untuk pertemuan ketiga memuat materi tentang $\mathrm{pH}$ larutan garam bersifat basa yang terhidrolisis parsial dan total. Berikut beberapa contoh desain LKS berbasis inkuiri terbimbing dapat dilihat pada gambar 2.

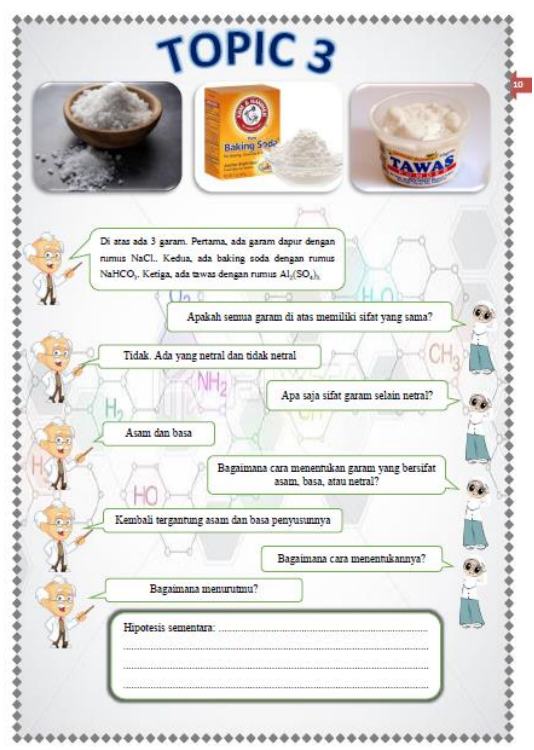

Gambar 2. Contoh Isi LKS

LKS didesain dengan warna yang cerah, memuat gambar dan karakter. Gambar dan karakter diharapkan dapat membantu siswa dalam mengingat dan memahami materi. Menurut Nurfausiah dan Suhardiman (2016) hanya diarahkan kepada kemampuan anak untuk menghafal informasi pada proses pembelajaran di dalam kelas. Dengan inkuiri terbimbing siswa akan menemukan sendiri konsepnya yang membuat siswa tidak hanya menghafal materi. 


\section{Langkah 4 Validasi Desain/Uji Kelayakan Valid}

Validasi bertujuan untuk menguji kelayakan isi, penyajian, kebahasaan dan kegrafisan. Kelayakan dinilai oleh 3 orang validator, 2 validator dari guru kimia dan 1 validator dari dosen pendidikan kimia. Pengambilan data menggunakan angket yang berisi 25 item pernyataan positif dengan skor 0,1 dan 2 . Adapun hasil validasi dari 3 validator dapat dilihat pada Gambar 3 dan Tabel 1.

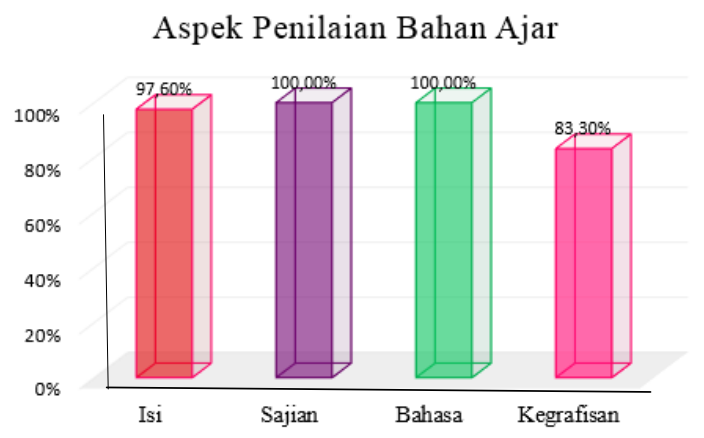

\section{Gambar 3. Rata-Rata Hasil Validasi LKS Oleh 3 Orang Validator Pada Setiap Aspek Penilaian}

Peneliti mendapat komentar dan saran pada aspek isi dan kegrafisan. Pada aspek isi, peneliti diminta untuk menekankan pada siswa mengenai rumus $\mathrm{pH}$ hidrolisis garam. Sedangkan pada aspek kegrafisan peneliti diminta untuk memperbesar ukuran gambar. Adapun hasil uji kelayakan valid pada setiap validator adalah sebagai berikut:

Tabel 1. Hasil konversi skor angket LKS dari 3 validator

\begin{tabular}{cccc}
\hline Validator & Skor $(\boldsymbol{\%})$ & Kriteria & Kategori \\
\hline I & 94 & Sangat layak & Tidak perlu revisi \\
II & 98 & Sangat layak & Tidak perlu revisi \\
III & 94 & Sangat layak & Tidak perlu revisi \\
\hline
\end{tabular}

Menurut Rizalini dan Sofyan (2018) validasi media dilakukan untuk mengukur kelayakan lembar kerja peserta didik berbasis inkuiri terbimbing ditinjau dari aspek media. Setelah proses validasi desain peneliti mendapat nilai 94 oleh validator 1 dengan kriteria sangat layak, mendapat nilai 98 oleh validator 2 dengan kriteria sangat layak dan mendapat nilai 94 oleh validator 3 dengan kriteria sangat layak. Dengan demikian hasil dari penilaian ahli tersebut disimpulkan bahwa LKS yang dikembangkan mendapat ratarata 95,33 dengan kriteria sangat layak. Meskipun begitu, peneliti tetap melakukan revisi berdasarkan saran dan komentar dari validator.

\section{Langkah 5 Revisi Desain}

Ada tiga hal yang perlu direvisi menurut validator. Pertama, rumus $\mathrm{pH}$ ditonjolkan dengan ditebalkan. Kedua, ukuran gambar larutan topik 2 diperbesar. Ketiga, tulisan $\mathrm{NH}_{4} \mathrm{~F}$ pada halaman 11 kurang jelas Perbandingan sebelum dan sesudah revisi dapat dilihat pada gambar 4, gambar 5 dan gambar 6. 

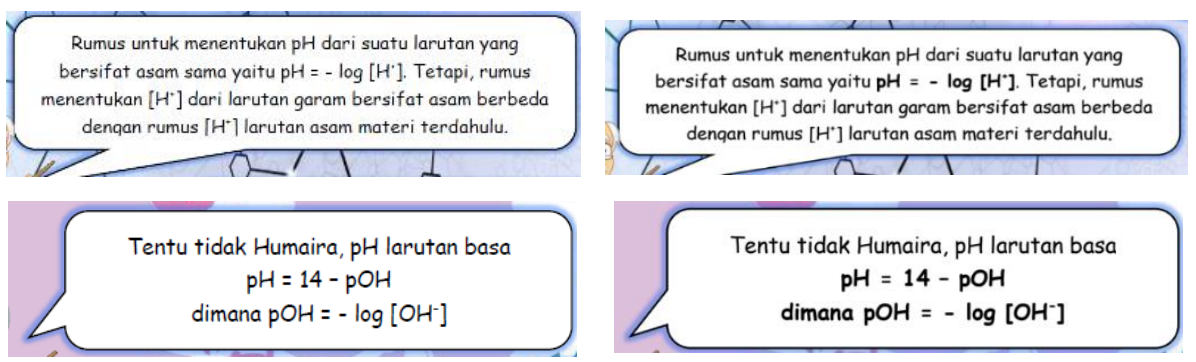

\section{Gambar 4. Perbandingan Sebelum dan Sesudah Revisi}

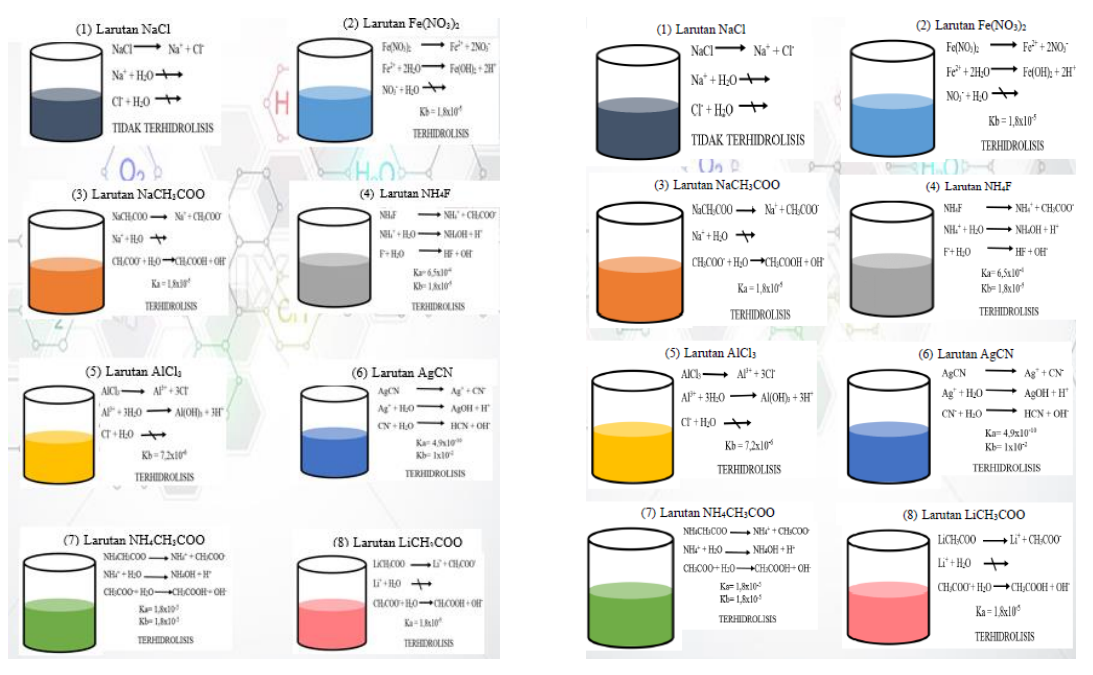

Gambar 5. Perbandingan Sebelum dan Sesudah Revisi
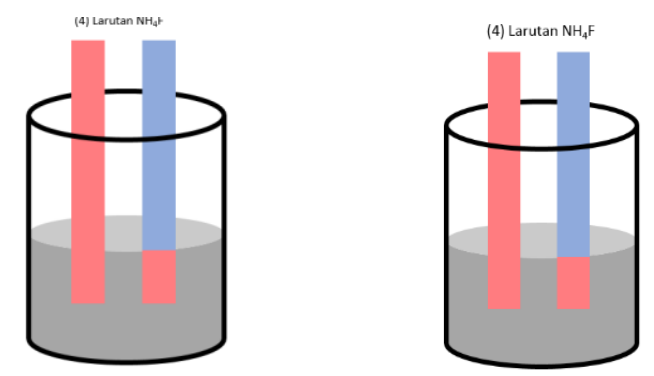

Gambar 6. Perbandingan Sebelum dan Sesudah Revisi

\section{Langkah 6 Uji Coba Produk}

Setelah produk melalui tahap validasi oleh ahli serta telah selesai diperbaiki, selanjutnya produk diuji cobakan dengan uji coba kelompok kecil pada siswa kelas XII 
MIA 1 MAN 1 Banjarmasin sebanyak 15 orang. Adapun hasil angket respon siswa terhadap LKS berbasis inkuiri terbimbing per-item pernyataan dapat dilihat pada gambar 7.

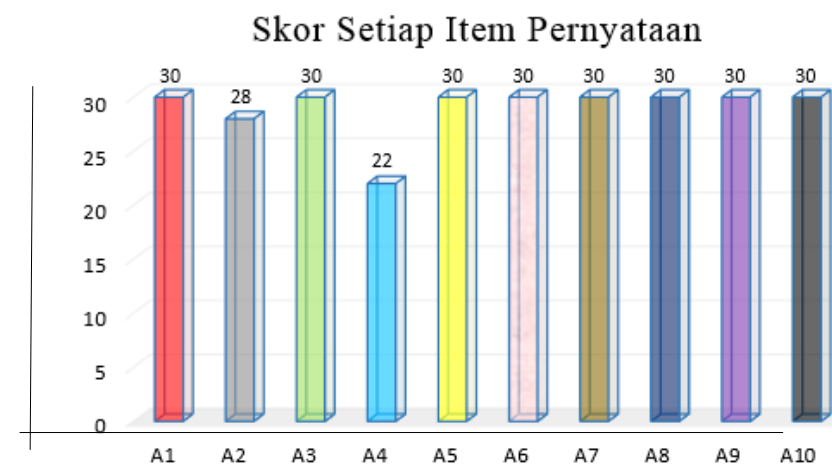

\section{Gambar 7. Hasil Rekapitulasi Setiap Item Pernyataan Angket Respon Terhadap LKS}

Apabila seluruh siswa menyatakan setuju (skor 2), berarti total skornya 30. Pada gambar 7 ada 2 pernyataan yang mendapat skor 1 (tidak setuju). Pertama, pernyataan ke2 mendapat skor total 28, artinya ada 2 orang siswa yang menyatakan tidak setuju, ulasan dari komentar dan saran siswa pada pernyataan tersebut adalah disediakan ruang antara contoh soal satu dengan yang lain agar tidak terlihat berat. Kedua, pernyataan ke4 mendapat skor total 22 , artinya ada 8 orang siswa yang menyatakan tidak setuju pada pernyataan tersebut, ulasan dari komentar dan saran siswa pada pernyataan tersebut adalah ada beberapa bagian kolom disediakan kecil, sehingga alangkah baiknya disediakan ruang yang lebih.

Setelah didapatkan data respon siswa per item pernyataan, selanjutnya data direkapitulasi kembali secara menyeluruh mengacu pada gambar 8. Adapun persentasi respon siswa terhadap LKS pada setiap kategori adalah sebagai berikut:

\section{Kategori Respon Siswa Terhadap LKS}

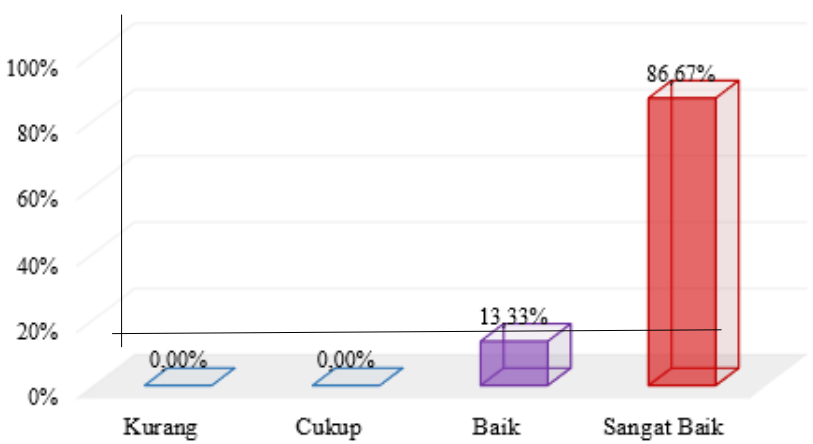

Gambar 8. Persentasi Respon Siswa Terhadap LKS Pada Setiap Kategori 
Pada tahap ini peneliti melakukan uji coba produk pada siswa kelas XII MIA 1 sebanyak 15 orang secara online dengan bantuan aplikasi WhatsApp untuk mengetahui respon siswa terhadap LKS berbasis inkuiri terbimbing. Uji coba kelompok kecil memperoleh hasil respon siswa dengan $0 \%$ pada kategori kurang dan cukup, 13,33\% pada kategori baik dan $86,67 \%$ pada kategori sangat baik. Menurut Rizalini dan Sofyan (2018) hasil dari uji coba kelompok kecil digunakan sebagai masukan oleh peneliti tentang keterbacaan produk yang dikembangkan sebelum diujicobakan ke lapangan.

\section{Langkah 7 Revisi Produk}

Ada dua hal yang perlu direvisi menurut hasil uji coba produk. Pertama, Beberapa ruang yang disediakan pada LKS tidak cukup untuk menulis. Kedua, beri jarak antara contoh soal satu dengan contoh soal yang lain. Perbandingan sebelum dan sesudah revisi dapat dilihat pada gambar 9, gambar 10 dan gambar 11.
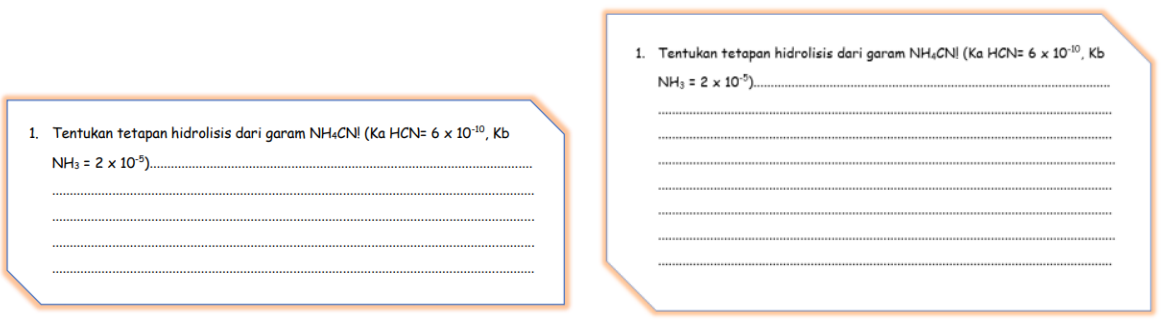

Gambar 9. Perbandingan Sebelum dan Sesudah Revisi

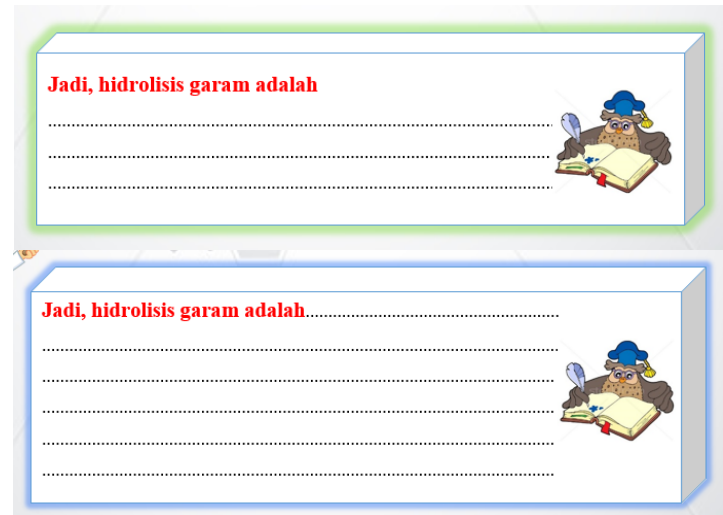

Gambar 10. Perbandingan Sebelum dan Sesudah Revisi 

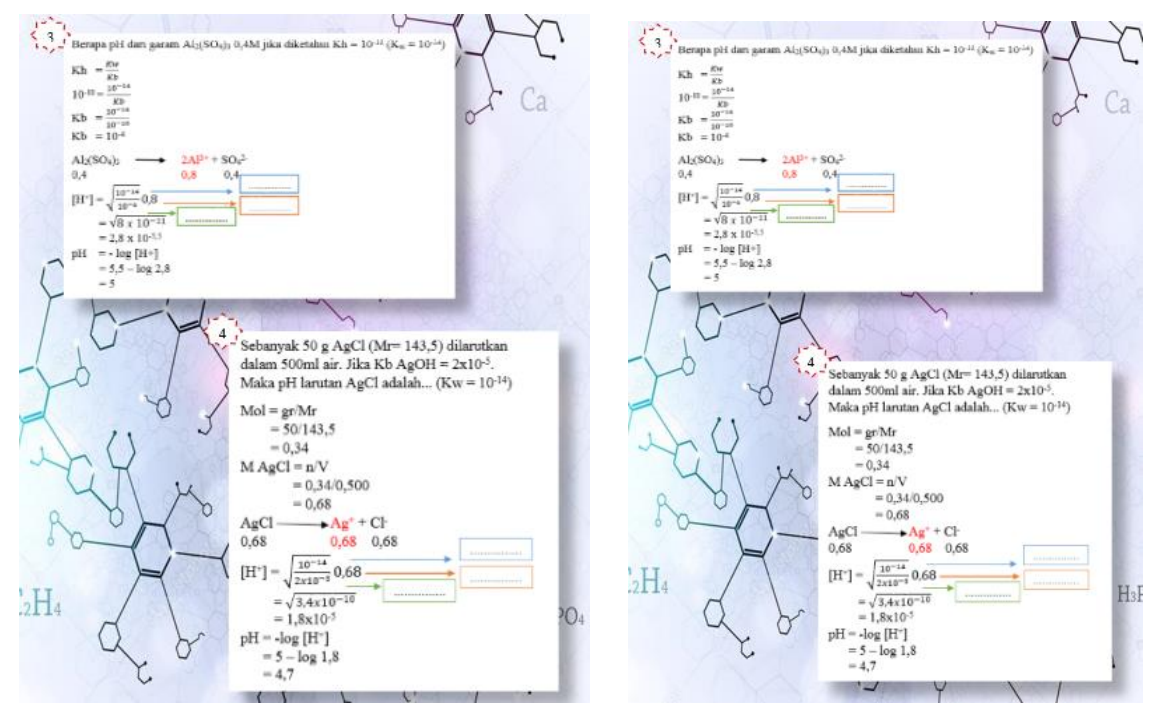

Gambar 11. Perbedaan Sebelum dan Sesudah Revisi

\section{Langkah 8 Uji Coba Pemakaian/ Uji Kelayakan Praktis}

Setelah melakukan revisi, peneliti kembali mengujikan produk terhadap siswa kelas XI MIA 1 dengan jumlah siswa 29 orang secara online. Peneliti mengajar dengan bantuan aplikasi Google Classroom dan WhatsApp. Peneliti tidak bisa terjun langsung ke lapangan karena adanya wabah covid-19 yang tidak memperbolehkan tatap muka langsung dan mengharuskan untuk jaga jarak dan tetap di rumah.

Pada pertemuan pertama, peneliti mengajarkan definisi, jenis dan sifat hidrolisis garam dengan bantuan LKS berbasis inkuiri terbimbing. Sebelum masuk ke materi, peneliti mengajak siswa mengingat materi sebelumnya, yaitu asam-basa dengan meminta siswa mencocokkan definisi yang sesuai dan mengingat contoh asam lemah, basa lemah, asam kuat dan basa lemah, serta menentukan produk yang terbentuk. Setelah itu, baru peneliti mengajar dengan menggunakan langkah inkuiri terbimbing.

Awalnya peneliti menyajikan topik, kemudian dibantu oleh karakter Humaira dan Professor untuk merangsang siswa dalam beriorientasi dan merumuskan masalah. Selanjutnya, siswa akan dibimbing untuk menentukan hipotesis sementara dari pertanyaan atau rumusan masalah yang sudah ditentukan. Siswa diajak berinvestigasi tertuju pada jawaban dari rumusan masalah yang ada. Langkah terakhir adalah merumuskan kesimpulan. Setiap langkah tersebut terjadi berulang pada setiap topik.

Respon siswa pada pertemuan pertama bagus. LKS berbasis inkuiri terbimbing membuat siswa berfikir kritis dan menghubungkannya dengan materi lain yang berkaitan. LKS berbasis inkuiri terbimbing juga membuat siswa aktif bertanya. Hal ini sejalan dengan penelitian yang dilakukan oleh Astuti dan Setiawan (2013) dimana dalam pembelajaran dengan menggunakan metode inkuiri terbimbing siswa terlibat aktif dalam pembelajaran dan menemukan konsep melalui kontruksinya sendiri.

Pada pertemuan kedua, peneliti mengajarkan tetapan hidrolisis dan $\mathrm{pH}$ larutan garam bersifat asam. Sama halnya dengan pertemuan pertama, peneliti mengajar dengan LKS dan diiringi langkah inkuiri terbimbing pada setiap topiknya. Respon siswa pada 
pertemuan kedua masih bagus. Pembelajaran berlangsung lancar, siswa meminta peneliti memberikan contoh soal untuk dikerjakan sebagai latihan.

Pada pertemuan ketiga, peneliti mengajarkan tentang $\mathrm{pH}$ larutan garam yang bersifat basa. Siswa aktif bertanya dan menyukai LKS yang ada berbagai macam contoh soal. Peneliti menyajikan berbagai tipe contoh soal dengan penyelesaian agar memudahkan siswa ketika mendapati soal yang serupa.

Setiap pertemuan dalam pembelajaran diakhiri dengan menyimpulkam materi yang telah dipelajari dalam pertemuan tersebut. Dalam sesi ini, peneliti juga bertanya kepada siswa apakah ada materi yang belum dipahami sebelum pembelajaran diakhiri dan dilanjutkan dengan latihan soal.

Peneliti meminta siswa untuk mengisi angket respon siswa terhadap pembelajaran menggunakan LKS berbasis inkuiri terbimbing setelah peneliti selesai mengajar materi hidrolisis garam. Adapun hasil angket respon siswa terhadap pembelajaran per-item pernyataan dapat dilihat pada gambar 12 .

Skor Setiap Item Pernyataan

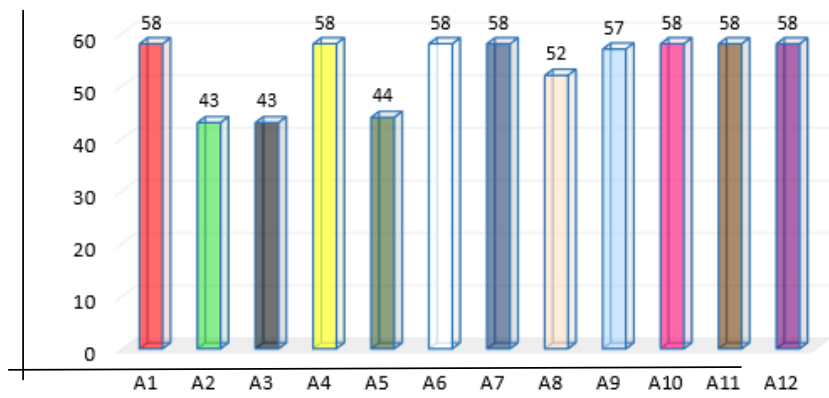

Gambar 12. Hasil Rekapitulasi Setiap Item Pernyataan Angket Respon Terhadap Pembelajaran

Hasil uji coba kelompok besar mendapat nilai rata-rata 22,24 dengan kriteria sangat baik. Ada 12 pernyataan dalam angket respon siswa terhadap pembelajaran. Setiap pernyataan memiliki skor yang bervariasi. Skor yang tertinggi adalah 58 terdapat pada pernyataan $1,4,6,7,10,11$ dan 12 yang artinya semua siswa setuju dengan pernyataan tersebut. Adapun ulasan dari komentar positif siswa mengenai LKS adalah sebagai berikut:

a) LKS yang dikembangkan sangat menarik dari segi tampilan maupun penyajian materi dapat menambah minat belajar dan memudahkan dalam mempelajari materi hidrolisis garam.

b) Siswa menyukai karakter yang ada dalam LKS karena menarik dan memudahkan dalam mempelajari materi hidrolisis garam

c) Gambar membuat lebih mudah memahami materi walau tidak praktik langsung

d) Soal yang ada beragam dilengkapi penyelesaian membuat lebih mudah memahami materi

Setelah didapatkan data respon siswa per item pernyataan, selanjutnya data direkapitulasi kembali secara menyeluruh mengacu pada gambar 13. Respon siswa terhadap pembelajaran dibagi menjadi 4 kategori yaitu kurang, cukup, baik dan sangat 
baik. Adapun persentasi respon siswa terhadap LKS pada setiap kategori adalah sebagai berikut:

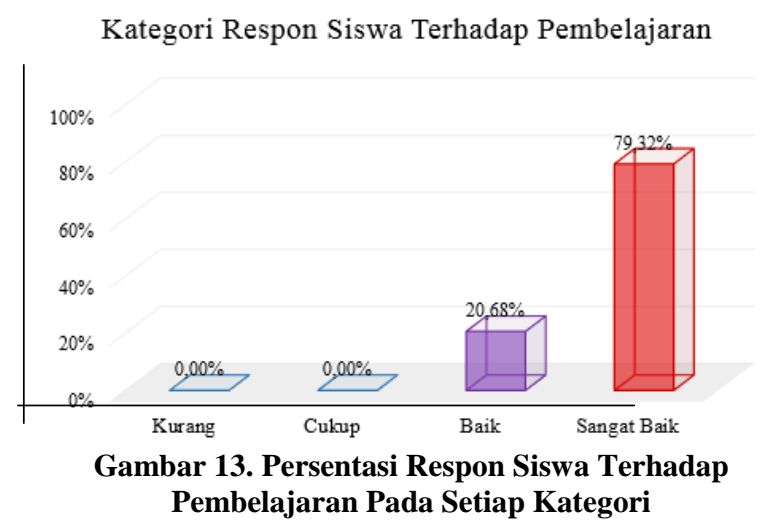

Menurut Sukarsih dkk (2018) tolak ukur keberhasilan dalam mengembangkan sebuah produk bahan ajar adalah dengan uji coba. Melalui uji coba, peneliti dapat mengetahui apakah produk yang dikembangkan layak atau tidak. Hasil uji coba menunjukkan $0 \%$ pada kategori kurang dan cukup, 20,68\% pada kategori baik dan $79,32 \%$ pada kategori sangat baik. Hal ini menunjukkan bahwa LKS berbasis inkuiri terbimbing layak digunakan sebagai bahan ajar pada materi hidrolisis garam.

\section{SIMPULAN}

Berdasarkan hasil penelitian maka dapat diambil kesimpulan bahwa LKS berbasis inkuiri terbimbing yang telah dikembangkan valid, praktis dan dapat dijadikan sebagai bahan ajar pada materi hidrolisis garam. Validitas bahan ajar dinilai oleh 3 orang ahli, dan mendapat nilai rata-rata 95,33 dengan kriteria sangat layak. Kepraktisan bahan ajar dinilai oleh 29 orang siswa, dan mendapat nilai rata-rata 22,24 dengan kriteria sangat baik.

\section{DAFTAR RUJUKAN}

Agustina., Masriani \& Sartika, R.P. (2015). Profil Kinerja Siswa Melalui Penerapan Model Pembelajaran Predict-Observe-Explain (POE) Pada Materi Hidrolisis Garam. Jurnal Pendidikan dan Pembelajaran Untan, 4(9), 1-13.

Astuti, Y \& Setiawan, B. (2013). Pengembangan Lembar Kerja Siswa (LKS) Berbasis Pendekatan Inkuiri Terbimbing Dalam Pembelajaran Kooperatif Pada Materi Kalor. Jurnal Pendidikan IPA Indonesia, 2(1), 88-92.

Ika, J., Sumarti, S.S. \& Widodo, A.R. (2017). Penerapan Model Pembelajaran Inkuiri Terbimbing Terhadap Self Efficacy dan Hasil Belajar Kimia pada Materi Koloid. Journal of Innovative Science Education, 6(1), 50-58.

Latifah, S., Setiawati. E. \& Basith, A. (2016). Pengembangan Lembar Kerja Peserta Didik (LKPD) Berorientasi Nilai-Nilai Agama Islam Melalui Pendekatan Inkuiri Terbimbing Pada Materi Suhu Dan Kalor. Jurnal Ilmiah Pendidikan Fisika AlBiRuNi, 5(1), 44-51. 
Ningsyih, S., Junaidi, E. \& Idrus, S.W.A. (2016). Pengaruh Pembelajaran Praktikum Berbasis Inkuiri Terbimbing Terhadap Kemampuan Berpikir Kritis Dan Hasil Belajar Kimia Siswa. Jurnal Pijar MIPA, 11(1), 55-59.

Nurfausiah \& Suhardiman. (2016). Pengaruh Model Pembelajaran Inkuiri Terbimbing Terhadap Hasil Belajar. Jurnal Pendidikan Fisika, 4(1), 10-13.

Matthew, M.B. \& Kenneth, I.O. (2013). A Study On The Effects Of Guided Inquiry Teaching Method On Students Achievement In Logic. International Researcher, 2(1), 135-140.

Pujiastuti, D., Ashadi \& Mulyani, S. (2018). Pengembangan Handout Kimia Berbasis Inkuiri Terbimbing Dilengkapi Media Grafis Pada Materi Ikatan Kimia MA. Prosiding Seminar Nasional Pendidikan Fisika, 3(1), 305-311.

Resita, I., Ertikano, C. \& Suana, W. (2016). Pengembangan Lembar Kerja Siswa (LKS) Berbasis Inkuiri Terbimbing Pada Materi Pokok Cahaya. Jurnal Pembelajaran Fisika, 4(2), 11-22.

Rizalini, R. \& Sofyan, H. (2018). Pengembangan Lembar Kerja Peserta Didik Kimia Berbasis Inkuiri Terbimbing Untuk Kelas XI IPA SMA/MA. Jurnal Inovasi Teknologi Pendidikan, 5(2), 103-114.

Sari, A.A., Hadisaputro, S. \& Nurhayati, S. (2017). Penerapan Inkuiri Terbimbing Berpendekatan Multiple Intelligences Terhadap Hasil Belajar Kimia. Chemistry in Education, 6(2), 57-62.

Sugiyono. 2016. Metode penelitian pendidikan (pendidikan kuantitatif, kualitatif, dan $R \& D)$. Bandung: Alfabeta.

Sukarsih, N.K.A., Wardani, R.R.A.A.K., \& Mashuri, M.T. (2018). Pengembangan Kartu Remi Kimia Menggunakan Model Pembelajaran TGT (Teams Games Tournament) Terhadap Hasil Belajar Siswa Pada Materi Pokok Sistem Koloid Kelas XI SMA KORPRI Banjarmasin. Dalton: Jurnal Pendidikan Kimia dan Ilmu Kimia. 1(1), 16-22. 